Marketing i Zarządzanie

nr 3 (44) 2016, s. 309-316

DOI: $10.18276 / \mathrm{miz} .2016 .44-28$ ISSN: 2450-775X | http://wnus.edu.pl/p1/miz/

\title{
Małgorzata Dolińska
}

Uniwersytet Marii Curie-Skłodowskiej w Lublinie

Wydział Ekonomiczny

e-mail: m.dolinska@umcs.lublin.pl

\section{Konsument jako partner przedsiębiorstwa w otwartych innowacjach}

Kod JEL: 031

Słowa kluczowe: otwarte innowacje, prosument, platformy innowacji, partner, przedsiębiorstwo, współpraca

Streszczenie. Celem artykułu jest przedstawienie roli zaangażowanych klientów jako partnerów przedsiębiorstw oraz uczestników procesów kreowania wartości w internecie, zgodnie z modelem otwartej innowacji. W artykule określono pojęcia i cechy charakterystyczne zamkniętych i otwartych innowacji oraz ich ewolucję w kierunku otwartych, sieciowych procesów innowacji, a także poddano analizie działalność zaangażowanych klientów na otwartych platformach innowacji w internecie, realizowaną z wykorzystaniem crowdsourcingu, koprodukcji oraz oprogramowania otwartego źródła. Rozwój nowych technologii, gospodarki opartej na wiedzy, społeczeństwa sieci oraz dynamiczne zmiany na rynkach wpływają na ewolucję konsumentów w zaangażowanych uczestników procesów kreowania wartości i wiedzy w otwartych projektach innowacyjnych realizowanych w internecie.

\section{Wprowadzenie}

Podstawą wzrostu konkurencyjności oraz wartości rynkowej innowacyjnych przedsiębiorstw w gospodarce opartej na wiedzy i społeczeństwie sieci jest ciągłe uczenie się oraz zarządzanie wiedzą wspólnie z uczestnikami rynku, w tym innymi przedsiębiorstwami i klientami w otwartych procesach innowacji. Tradycyjny liniowy proces innowacji (zamknięta innowacja) realizowany w całości 
w przedsiębiorstwie ulega ewolucji w kierunku otwartego (przekraczającego jego granice), coraz częściej sieciowego procesu innowacji, realizowanego przez firmę w trakcie współpracy z partnerami, klientami z wykorzystaniem ich wspólnej wiedzy, razem rozwijanej dla potrzeb innowacji, ich dyfuzji i komercjalizacji.

Celem artykułu jest przedstawienie roli zaangażowanych klientów jako partnerów przedsiębiorstw oraz uczestników procesów kreowania wartości w internecie, zgodnie z modelem otwartej innowacji. W artykule scharakteryzowano pojęcie otwartej innowacji. Opisano zasady oraz sposoby rozwijania przez firmy masowej współpracy z klientami jako partnerami na otwartych platformach innowacji - OPI (Open Innovation Web-based Platforms) w internecie, z wykorzystaniem crowdsourcingu (wiedzy thumu), koprodukcji (common-based peer production) oraz oprogramowania otwartego źródła (open source software). $\mathrm{W}$ otwartych innowacjach firmy wykorzystują wiedzę pochodzącą z zewnątrz (eksploracja), w tym od klientów zaangażowanych w rozwój innowacji, również na OPI w internecie oraz eksploatację wiedzy (przepływ na zewnątrz) celem prowadzenia ekspansji na rynkach innowacji i maksymalizacji zysków ze sprzedaży innowacji.

\section{Idea otwartych innowacji}

Otwarta innowacja jest określana jako systematyczne pozyskiwanie wiedzy, jej transfer wzdłuż procesów innowacji oraz wykorzystanie wewnątrz oraz na zewnątrz organizacji. Istotne cechy charakterystyczne otwartej innowacji to celowy, ukierunkowany przepływ wiedzy i własności intelektualnych do wewnątrz oraz na zewnątrz przedsiębiorstwa, uwarunkowany tworzeniem potrzebnej wiedzy poza firmą oraz jej wykorzystaniem, przyspieszającym rozwój innowacyjny firmy (Chesbrough, Vanhaverbeke, West, 2006, s. 1; Lichtenthaler, 2011, s. 77).

W modelu zamkniętej innowacji przedsiębiorstwo prowadzi własne prace $\mathrm{B}+\mathrm{R}$, a ich rezultaty wykorzystuje $\mathrm{w}$ swoich produktach innowacyjnych, które samodzielnie wprowadza na rynek. W modelu otwartej innowacji przedsiębiorstwo korzysta z zewnętrznych źródeł wiedzy lub rozwiązań innowacyjnych oraz systematycznie stosuje strategię rozwoju innowacyjnego w oparciu o wiedzę specjalistyczną powstającą na zewnątrz, którą wykorzystuje w swoich innowacjach oraz ich wprowadzaniu na nowe rynki (Henttonen, Pussinen, Koivumaki 2012, s. 136-137).

Model procesu innowacji przeszedł transformację od liniowego, zamkniętego wewnątrz przedsiębiorstwa w kierunku otwartego na zewnętrzne zasoby wiedzy procesu, coraz częściej realizowanego w obszarze sieci. Pojęcie sieci innowacji oznacza organizację, w której dwie lub więcej niezależnych firm współpracuje ze sobą w trakcie realizacji jednej, wielu czynności lub całych otwartych procesów innowacji. W otwartym procesie innowacji partnerzy współpracują ze 
sobą w oparciu o udostępniane przez nich dla potrzeb realizacji czynności procesu zasoby wiedzy, a także razem tworzoną lub rozwijaną wiedzę, co prowadzi do efektów synergicznych wzrostu jej wartości oraz efektywnego wykorzystania w innowacjach (Dolińska, 2015, s. 325). Klienci stają się cennym źródłem wiedzy wykorzystywanej w otwartych innowacjach, a orientacja na klienta jest uważana za ważny atrybut rozwoju współczesnego przedsiębiorstwa.

Proces innowacji jest określany dynamicznie jako ciąg powtarzających się w czasie czynności od powstania pomysłu na innowację, jej opracowanie, wdrożenie, promocję i sprzedaż na rynku, aż po dyfuzję oraz dalszy rozwój w czasie. Każda ze składowych czynności procesu, a także ich dowolny zestaw jest również procesem innowacji, w którym występuje kooperacja między dostawcami oraz klientami wiedzy. Efekt wykonania dowolnej czynności, zestawu czynności, całego procesu, posiadający swoją wartość rynkową, jest uznawany za innowację (produkt o dodanej wartości wiedzy), jeśli została w niej wykorzystana nowa wiedza lub w nowy sposób wiedza istniejąca do tej pory. Uczenie się firm partnerskich w obszarze sieci innowacji, które współpracują i jednocześnie konkurują ze sobą $\mathrm{w}$ trakcie wspólnego zarządzania wiedzą, również z klientami wzdłuż procesów innowacji, prowadzi do stałego rozwoju wiedzy i jej wykorzystania w innowacjach (Dolińska, 2010, s.14-15; Dolińska, 2015, s. 324).

W gospodarce i społeczeństwie rozwijane są następujące sieci innowacji, w których realizowane są otwarte innowacje: narodowe, regionalne systemy innowacji, parki naukowo-technologiczne, klastry, inkubatory przedsiębiorczości, formalna kooperacja przedsiębiorstw z innymi firmami (dostawcami wiedzy, innowacji, zapewniającymi wsparcie finansowe dla rozwoju innowacji, usługowymi w obszarze komercjalizacji, dyfuzji innowacji), również konkurentami, $\mathrm{z}$ jednostkami $\mathrm{B}+\mathrm{R}$, szkołami wyższymi, instytucjami transferu wiedzy/innowacji, firmami badań marketingowych i analiz rynków, z konsumentami indywidualnymi (systemy CRM - zarządzania relacjami z klientami, współpraca z klientami na OPI w internecie), również nieformalne formy kooperacji oparte na relacjach międzyludzkich, takie jak kluby innowatorów, przedsiębiorców (Dolińska, 2014, s. 224).

Stosowanie przez firmy uczestniczące w otwartym procesie innowacji zasad marketingu relacji, wykorzystanie systemu CRM, OPI funkcjonujących w internecie, ułatwia klientom aktywny udział w tworzeniu i doskonaleniu oferty firmy, zgodnie z ich aktualnymi i przewidywanymi oczekiwaniami oraz preferencjami, a jednocześnie przynosi firmom efekty synergiczne w rozwoju innowacyjnym.

\section{Wspólpraca klientów z firmami zgodnie z ideą otwartych innowacji na OPI w internecie}

Na podstawie badań ankietowych na temat działalności innowacyjnej i potencjału innowacyjnego przedsiębiorstw, przeprowadzonych przez autorkę w 64 
przedsiębiorstwach innowacyjnych województwa lubelskiego w 2009 roku, wynika, że większość badanych firm utrzymywała długookresowe, oparte na przepływie wiedzy relacje ze swoimi klientami indywidualnymi (65,6\% firm), klientami instytucjonalnymi (92,2\% firm), także - współpracownikami (klientami indywidualnymi, instytucjonalnymi) w procesach innowacji (56,3\% firm). Ponadto w większości, tj. 60,9\% badanych firm, źródłem innowacji byli klienci. Przedstawione wyniki badań świadczą o orientacji większości badanych firm na otwarte rynki innowacji, na których kształtowane są kreujące dodatkową wartość wiedzy relacje z partnerami (klientami instytucjonalnymi oraz indywidualnymi) w trakcie wykonywania czynności procesów innowacji. Wyniki badań przeprowadzone przez GUS (Działalność innowacyjna ..., 2015, s. 104) pokazują, że 9,8\% przedsiębiorstw przemysłowych oraz $9,7 \%$ przedsiębiorstw usługowych oceniło współpracę z klientami (na tle innych partnerów firmy) w latach 2012-2014 za najbardziej korzystną dla swojej działalności innowacyjnej.

Coraz więcej firm ma świadomość możliwości i zalet korzystania z potencjału społeczności klientów, pracowników, partnerów, interesariuszy jako źródła informacji, wiedzy i innowacji na OPI. OPI mogą powstawać z inicjatywy pojedynczych osób (platformy, które są otwarte dla innych osób jako ich użytkowników), pojedynczej firmy lub wielu firm (otwierających na platformie swoje granice w trakcie współpracy ze sobą oraz innymi ludźmi jako jej użytkownikami). Uczestnicy takich platform, odpowiadając na potrzeby firm, współpracują ze sobą, wspólnie biorąc udział w powstawaniu pomysłów, proponują nowe koncepcje i trendy, prezentują rozwiązania, aby wygrać we wzajemnym współzawodnictwie lub uzyskać nagrodę. OPI to ogólny termin charakteryzujący rozszerzanie funkcjonowania platform dla różnych form uczestnictwa i współpracy, takich jak crowdsourcing (np. platforma Innocentive), powszechnego udziału w produkcji (koprodukcja, np. Wikipedia), zastosowanie oprogramowania otwartego źródła (np. opracowanie koncepcji Fiata Mio online). Są one nowym narzędziem integrującym różnych członków innowacyjnych społeczności internetowych (osoby, firmy) (Battistella, Nonino, 2012, s. 557-559), w tym klientów aktywizujących $\mathrm{w}$ internecie swoją działalność innowacyjną z korzyścią dla firm i rynków.

Nowy konsument, który partycypuje w produkcji, nazywany jest prosumentem (producer-consumer; producent-klient). Prosumenci są twórczymi osobami, grupami osób, które utrzymują relacje z firmą i stają się wartościowym dla niej aktywem, jeżeli osobiście angażują się w tworzenie, rozwój jej produktów, kreowanie dla niej wartości (Izvercian, Seran, Buciuman, 2013, s. 388). Prosumenci należą do nowej generacji klientów, którzy są użytkownikami internetu, stosują nowe technologie, posiadają odpowiednią wiedzę dla potrzeb współpracy w otwartych innowacjach oraz chęć lub pasję do kreowania koncepcji rozwiązań 
innowacyjnych, produktów lub ich projektowania, testowania bądź wprowadzania na rynek za pośrednictwem OPI. Jako aktywni użytkownicy takich platform wpływają na działania innowacyjne realizowane przez innych członków społeczności internetowych.

Rozwój OPI staje się możliwy dzięki nowej technologii, rozwojowi internetu, zaangażowaniu prosumentów oraz stosowaniu w praktyce idei otwartej innowacji. Za pośrednictwem OPI firmy są w stanie dotrzeć do dużej, nieznanej populacji, zapraszając jej twórczych przedstawicieli do wykorzystywania ich wiedzy w kreowaniu nowych wartości wykorzystywanych w rozwiązaniach innowacyjnych. Użytkownicy OPI mogą być uczestnikami wszystkich czynności procesu innowacji, rozpoczynając od prognozowania zmian na rynkach, rozpoznawania przyszłych potrzeb klientów, kolejno zgłaszania koncepcji rozwiązań, pomysłów na zmiany, udziału w rozwoju produktów, ich zastosowaniu, komercjalizacji.

Zastosowanie idei otwartej innowacji na OPI wpływa na zasadnicze zmiany w działalności innowacyjnej prowadzonej przez przedsiębiorstwa w internecie. Użytkownicy OPI nie tylko biorą udział w powstawaniu idei, pomysłów na innowacje, nowe produkty, ale także dzielą z przedsiębiorstwami na platformach usługi, przestrzeń i zyski, jakie przynoszą im nowe rozwiązania, będące efektem czynności procesów innowacji, które tradycyjnie były realizowane samodzielnie przez firmy. Przedsiębiorstwa proponują prosumentom udział w zyskach, jakie przynosi zastosowanie ich wiedzy w rozwiązaniach innowacyjnych wdrożonych w gospodarce (Battistella, Nonino, 2012; Kohler, 2015).

\section{Udział prosumentów w crowdsourcingu, koprodukcji i oprogramowaniu otwartego źródła}

Proces crowdsourcingu (wykorzystania thumu jako źródła wiedzy) jest definiowany jako działanie pracowników firmy połączone z outsourcingiem wiedzy, kierowane do nieokreślonej, dużej sieci ludzi w formie otwartego ogłoszenia. Platformy crowdsourcingu powstają z inicjatywy pojedynczej firmy i są realizowane przez pracowników przedsiębiorstwa lub ich interesariuszy. Crowdsourcing jest sponsorowany przez organizację, która bezpośrednio zarządza „ttumem" w celu efektywnego wykorzystywania jego wiedzy dla potrzeb realizacji swoich celów i zadań. Rozwiązanie koprodukcji - powszechnego udziału w produkcji - odnosi się do nowego społeczno-ekonomicznego modelu produkcji, w którym występuje współpraca dużej liczby osób w trakcie opracowywania dużych projektów, bez wykorzystywania tradycyjnych, hierarchicznych struktur organizacji. Oprogramowanie otwartego źródła łączy zaś osoby, które mogą pochodzić z odległych geograficznie miejsc, ale mają pasję, chęci i wiedzę do aktywnego udziału we wspólnych programach rozwojowych (Battistella, Nonino, 2012, s. 558; Füller, Matzler, Hutter, Hautz, 2012, s. 248-249). 
Współpraca z dużą liczbą prosumentów na platformie crowsourcingu może redukować czas wprowadzania nowych produktów na rynek lub skutecznego rozwiązywania problemu firmy. Przykładowo społeczność platformy Quirky od rozpoczęcia jej działalności w 2009 roku wykreowała 400 produktów. W tym przypadku Quirky koordynuje cały proces rozwoju produktu od powstania koncepcji, opracowania produktu do nadania mu nazwy. Następnie przedsiębiorcy produkują i dystrybuują produkty online oraz za pośrednictwem detalistów (Kohler, 2015, s. 65).

Przykładem koprodukcji jest platforma Innocentive, funkcjonująca zgodnie $\mathrm{z}$ ideą otwartych innowacji oraz crowdsourcingu, gdzie uczestnicy mogą przedstawiać własne pomysły rozwiązań innowacyjnych w odpowiedzi na problemy zgłaszane przez firmy. Firma przedstawiając problem, proponuje również nagrodę za jego rozwiązanie. Rosnąca liczba użytkowników tej platformy oraz oferowane im nagrody za najlepsze rozwiązania powodują, że staje się ona coraz bardziej popularnym miejscem poszukiwania innowacyjnych rozwiązań. W ten sposób rozwija się otwarty rynek innowacji. Z usług tej platformy korzystały m.in. Procter \& Gamble, The Economist, Nature Publishing Group, NASA (Andrejczuk, 2013, s. 83).

Wprowadzenie koncepcji otwartego źródła do różnych dziedzin gospodarki i w społeczeństwie jest powiązane z ewolucją procesu innowacyjnego, w którym najistotniejsze znaczenie ma wspólna wiedza poszczególnych jednostek (osób, firm) uczestniczących $w$ jego realizacji oraz nieformalne relacje, jakie kształtują się między nimi w trakcie współpracy opartej na kreowaniu i wykorzystaniu wiedzy w innowacjach. Termin otwarte źródło najczęściej określa koncepcję otwartego oprogramowania stosowaną w branży IT. Stanowi ona sposób prowadzenia współpracy w zakresie B+R dla produktu końcowego, czego przykładem jest system Linux. W 1991 roku Linus Torvalds, student Uniwersytetu w Helsinkach, zaprezentował pierwszą wersję Linuksa, a informację o tym systemie operacyjnym umieścił na jednym $z$ uniwersyteckich serwerów, zachęcając innych programistów do jego wspólnego rozwijania. Na początku studenci i programiści brali udział w pisaniu tego programu, a Torvalds zajmował się łączeniem zgłaszanych poprawek i opracowań. Z czasem do projektu włączyły się największe światowe firmy informatyczne, IBM, HP czy Intel, które oferują wynagrodzenie dla programistów pracujących nad systemem, oraz zapewniają im niezbędne narzędzia technologiczne czy wsparcie marketingowe. Powstał zarząd Linuksa, którego zadaniem jest podejmowanie decyzji o kierunkach jego dalszego rozwoju, jednak Linux Inc. nie stał się tradycyjną firmą - nie ma własnej siedziby oraz nie publikuje raportów rocznych (Portal...). 


\section{Podsumowanie}

Rosnąca dynamika zmian na rynkach intensyfikuje rozwój innowacyjny firm, ukierunkowany na zaspokajanie ewoluujących w czasie potrzeb i oczekiwań klientów, którzy przez sieci społeczności w internecie mają coraz większy wpływ na kreowanie i rozwój rozwiązań innowacyjnych, na które czeka rynek. Wiele firm czy osób rozwija swoje twórcze pomysły, rozwiązania, przedsięwzięcia w projekty innowacyjne na sprawnie funkcjonujących OPI w internecie. Działalność OPI, w tym oparta na crowdsourcingu, koprodukcji i oprogramowaniu otwartego źródła jest odpowiedzią na szybko zmieniające się potrzeby klientów, krótsze cykle życia produktów oraz rosnącą konkurencyjność na rynkach. Firmy korzystając z wiedzy użytkowników platform jako twórców, poznają rzeczywiste i aktualne potrzeby, oczekiwania klientów oraz oferują im produkty o jak największej wartości. Dobrze prosperujące OPI rozwijają się szybko dzięki stosowanej w praktyce idei otwartych innowacji oraz efektom sieci (współpracy między firmami oraz klientami). Pozyskiwanie przez platformy twórców staje się większą atrakcją dla klientów, którzy z kolei przyciągają kolejnych twórców, co w rezultacie powoduje kreowanie większych korzyści dla klientów itd. Dynamika rozwoju OPI jest rezultatem twórczych inicjatyw jej uczestników oraz transakcji zawieranych na platformie.

\section{Bibliografia}

Andrejczuk, M. (2013). Otwarte innowacje - w drodze ku intelektualnemu przewrotowi. W: N. Ćwik (red.), Wspólna odpowiedzialność. Rola innowacji (s. 80-86). Forum Odpowiedzialnego Biznesu. Pozyskano z: http://odpowiedzialnybiznes.pl/public/files/FOB\%20rola\%20innowacji\% 20176x250\%202013-03-05\%20calosc\%20pojedyczne\%20strony.pdf.

Battistella, C., Nonino, N. (2012). Open innovation web-based platforms: the impact of different forms of motivation on collaboration. Innovation: Management, Policy \& Practice, 14 (4), $557-575$

Chesbrough, H., Vanhaverbeke, W., West, J. (red.). (2006). Open innovation: researching a new paradigm. Oxford, UK: Oxford University Press.

Dolińska, M. (2015). Knowledge based development of innovative companies within the framework of innovation networks. Innovation: Management, Policy \& Practice, 17 (3), 323-340.

Dolińska, M. (2014). Open innovation. W: A. Jaki, B. Mikuła (red.), Knowledge-economy - society. Managing organizations: concepts and their applications (s. 221-228). Cracow: University of Economics Press.

Dolińska, M. (2010). Innowacje w gospodarce opartej na wiedzy. Warszawa: PWE.

Działalność innowacyjna przedsiębiorstw w latach 2012-2014. Informacje i opracowania statystyczne (2015). Warszawa: GUS. Urząd Statystyczny w Szczecinie.

Füller, J., Matzler, K., Hutter K., Hautz, J. (2012). Consumers' creative talent: which characteristics quality consumers for open innovation projects? An exploration of asymmetrical effects. Creativity and Innovation Management, 21 (3), s. 247-261. 
Henttonen K., Pussinen, P. Koivumaki, T. (2012). Managerial perspective on open source collaboration and networked innovation. Journal of Technology, Management \& Innovation, 7 (3), 135-147.

Izvercian, M., Seran, S.A., Buciuman, C.F. (2013). Transforming usual consumers into prosumers with the help of intellectual capital collaboration for innovation. International Journal of Information and Education Technology, 3 (3), 388-392.

Kohler, T. (2015). Crowdsourcing-based business models: how to create and capture value. California Management Review, 57 (4), 63-83.

Lichtenthaler, U. (2011). Open innovation: past research, current debates, and future directions. Journal of Management Perspectives, 25 (2), 75-93.

Portal Innowacji. Pozyskano z: www.pi.gov.pl.

\section{Consumer as a Partner of an Enterprise in Open Innovation}

Keywords: open innovations, prosumer, innovation platforms, partner, enterprise, cooperation

Summary. The objective of the article is presenting the role of prosumers as partners of enterprises and participants of value creation processes in internet, in accordance with open innovation model. The ideas and characteristics of close and open innovations are determined and the activity of prosumers engaged on Open Innovation Web-based Platforms, realized with the use of crowdsourcing, coproduction and open source software are analyzed in the article. Development of new technologies, knowledge based economy, network society and turbulent markets influence the evolution of consumers into engaged participants of value and knowledge creation processes in open innovation projects which are executed in internet.

Translated by Matgorzata Dolińska

\section{Cytowanie}

Dolińska, M. (2016). Konsument jako partner przedsiębiorstwa w otwartych innowacjach. Marketing $i$ Zarządzanie, 3 (44), 309-316. 